Journal of British Studies 61 (January 2022): 1-25. doi:10.1017/jbr.2021.126

(C) The Author(s), published by Cambridge University Press on behalf of the North American Conference on British Studies. This is an Open Access article, distributed under the terms of the Creative Commons Attribution-NonCommercial-NoDerivatives licence (https://creativecommons.org/licenses/by-nc-nd/4.0/), which permits non-commercial re-use, distribution, and reproduction in any medium, provided the original work is unaltered and is properly cited. The written permission of Cambridge University Press must be obtained for commercial re-use or in order to create a derivative work.

\title{
Flexible Workers: The Politics of Homework in
}

\section{Postindustrial Britain}

\section{Helen McCarthy}

\begin{abstract}
This article opens up a new perspective on market liberalism's triumph in the late twentieth century through an examination of the political battles that were fought in Britain over the regulation of homework. Ubiquitous in the late Victorian era, this form of waged labor was curtailed by Edwardian wage regulations but resurged in the 1970s as a result of competition from low-wage economies abroad and fast-changing consumer tastes. Alongside growing use of homeworkers in consumer industries, new information technologies made it increasingly possible for some forms of professional work to move into the home. This article explores the debates that swirled around these different forms of homework, pitting antipoverty campaigners, feminists, and activists against ministers, employers, and civil servants. It shows how Conservative and New Labour governments failed to recognize the structural similarities between Victorian-style "sweated" labor and the emerging world of telework, freelancing, and self-employment, and how the intellectual excitement generated by Britain's transition toward a postindustrial future dovetailed with the New Right commitment to deregulation and the creation of "flexible" labor markets. A brief comparison with homework in the United States underlines the value of local, particular histories to our larger understanding of ideological change in modern societies.
\end{abstract}

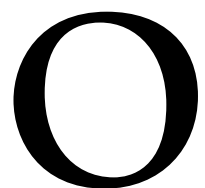

n 9 February 1978, the Labour MP for Stoke-on-Trent, Jack Ashley, rose from his seat in the Commons to warn parliamentary colleagues that "the scandal of sweated labour" had returned to Britain. Its particular form was homework, a type of waged manual labor typically carried out on a kitchen table or in a spare room and paid by the piece. Ubiquitous in the light manufacturing industries of the late Victorian era, homework had been severely curtailed by the wage regulations of the landmark Trade Boards Act (1909) but was now resurging. Fast-moving consumer tastes and competition from low-wage economies in the developing world had prompted firms and retailers to restructure their supply chains, making heavy use of small contractors and homeworkers. Ashley judged there to be at least a quarter of a million of the latter in Britain, concentrated among women and minorities: "These prisoners of poverty are mainly women with young children, disabled people or immigrants. They are the under-privileged of our society who should be generously assisted, whereas they are ruthlessly

Helen McCarthy is professor of modern and contemporary British history at the University of Cambridge. She thanks Ursula Huws, Simon Crine, and numerous colleagues at the University of Cambridge for their invaluable input and advice during the writing of this article. Please direct any correspondence to hm234@cam.ac.uk. 
exploited." Ashley set out a ten-point plan of action, which included a statutory minimum wage for homeworkers, regularization of their employment status, and stronger enforcement of health and safety legislation in the home. ${ }^{2}$

Ashley's was not a lone voice pleading the case of low-paid homeworkers in the late 1970s. For much of the century, policy makers on the left had assumed that the growth of trade unionism and the extension of the Trade Boards system (renamed the Wages Councils in 1945) would together solve the problem of endemic low pay. The rationalization of industry would make the homeworker less attractive to the employer, while full employment and a generous welfare state would reduce household dependence on casual wage earning by women at home. The economic turbulence experienced by Western societies in the 1970s shook this optimistic narrative. As the postwar model of secure, full-time employment began to unravel, campaigners moved to publicize the plight of those trapped in precarious jobs, among whom homeworkers featured prominently. In his remarks, Ashley drew heavily on the Statement on Homeworking published earlier in the year by the Trade Unions Congress, ${ }^{3}$ while flurries of pamphlets on the subject were issued over the following decade by anti-poverty pressure groups and grassroots organizations. The Labourled Greater London Council was a powerful ally between 1981 and 1986 and gave particular weight to the exploitation of homeworkers from ethnic minority communities. Yet the policy response was minimal. The Labour government of 1975-1979 took steps to strengthen inspection and enforcement of Wages Council regulations, but momentum quickly stalled under Margaret Thatcher's Conservative governments in the 1980s. Homeworkers benefited from the National Minimum Wage introduced by New Labour in 1998, but there was no move to introduce the wider protections that Ashley had advocated two decades earlier, despite sustained lobbying by campaigners and a string of private members bills presented to Parliament in the intervening period. 4

As this brief narrative suggests, the history of homework in the late twentieth century is deeply entangled in other histories: of low pay, migration, and women's labor, of trade unionism and the new urban left, of the globalizing economy and the shifting role of the state in regulating labor markets. The nineteenth- and early twentieth-century prelude to this story has been well told by scholars studying the sweating system and the Trade Boards Act that set minimum rates in named trades in which homework was pervasive. ${ }^{5}$ Historians have attended especially closely to how gender and race operated within this low-wage economy. Sweating was strongly associated with "foreign" labor, predominantly European Jews who found work in the tailoring trades, and with wage earning by married women. ${ }^{6}$

\footnotetext{
1 "Homeworkers," 9 February 1978, Parliamentary Debates, House of Commons, 5th ser., vol. 943, cols. 1812-22, at 1813-34.

2 "Homeworkers," 9 February 1978, Parliamentary Debates, 1815-16.

3 Trades Union Congress, Statement on Homeworking (London, 1978).

${ }^{4}$ Private members bills on the subject were introduced in 1978, 1981, 1990, 1991, 1995, and 1996.

5 The fullest and most rigorous account is Sheila Blackburn, A Fair Day's Wage for a Fair Day's Work? Sweated Labour and the Origins of Minimum Wage Legislation in Britain (Aldershot, 2007); see also Duncan Bythell, Sweated Trades: Outwork in Nineteenth-Century Britain (London, 1978); James Schmiechen, Sweated Industries and Sweated Labour: The London Clothing Trades, 1860-1914 (Urbana, 1984).

${ }^{6}$ David Feldman, Englishmen and Jews: Social Relations and Political Culture, 1840-1914 (London, 1994), especially chap. 8; Jenny Morris, Women Workers and the Sweated Trades: The Origins of
} 
Both groups were considered threats to the model of masculine breadwinning that became ideologically entrenched in most industrial capitalist economies in this period. The immigration restrictions introduced by the 1905 Aliens Act were heavily influenced by anxieties about sweated labor, while the first four industries to fall within the scope of the Trade Boards system had largely female workforces. As historians have noted, it was deeply significant that the workers deemed in need of "protection" by minimum wage legislation were predominantly women.7 Gender thus helps explain how a liberal state with a voluntarist tradition of industrial relations could justify intervening in the wage-setting process.

By contrast, homework in later twentieth-century Britain has received scant attention from historians. ${ }^{8}$ This gap is despite growing efforts in the field to rethink narratives of change and continuity since the 1970 s and mounting policy interest in precarity and low pay in the wake of the 2008 financial crisis. ${ }^{9}$ I offer here a preliminary contribution to this under-researched subject, indicating how homework offers a useful analytical lens for historians of the contemporary period. I do so by pinning my discussion to two central questions. Why, unlike in the pre-First World War period, were British governments between the 1970s and 1990s so reluctant to regulate homework? And what can this political struggle reveal about states and labor markets in the late twentieth and early twenty-first centuries?

In answering these questions, one readily available interpretative framework is the broad ideological shift from postwar social democracy to market or "neo" liberalism. ${ }^{10}$ What Colin Crouch has called "enriched" standard employment was an

Minimum Wage Legislation (Aldershot, 1986); Sonya O. Rose, Limited Livelihoods: Gender and Class in Nineteenth-Century England (London, 1992), chap. 4; Shelley Pennington and Belinda Westover, $A$ Hidden Workforce: Homeworkers in England, 1850-1985 (Basingstoke, 1989).

${ }^{7}$ Deborah Thom, "Free from Chains? The Image of Women's Labour in London, 1900-1920," in Metropolis London: Histories and Representations since 1800, ed. David Feldman and Gareth Stedman Jones (London, 1989), 85-99; Kristen Huneault, Difficult Subjects: Working Women and Visual Culture, Britain, 1880-1914 (Farnham, 2002); Blackburn, Fair Day's Wage?; Helen McCarthy, Double Lives: A History of Working Motherhood (London, 2020), chap. 2.

${ }^{8}$ The main text is Mark Wilding, "Organising Homeworkers in Britain over the Last Three Decades" (PhD diss., University of Manchester, 2005), which maps local and national-level activism around industrial homeworking but does not cover white-collar homework and is based on limited archival research.

${ }^{9}$ Lawrence Black, Hugh Pemberton, and Pat Thane, eds., Reassessing 1970s Britain (Manchester, 2013); Emily Robinson et al., "Telling Stories about Post-war Britain: Popular Individualism and the 'Crisis' of the 1970s," Twentieth Century British History 28, no. 2 (2017): 268-304; Matthew Hilton, Chris Moores, and Florence Sutcliffe-Braithwaite, eds., "New Times Revisited: Britain in the 1980s," special issue of Contemporary British History 31, no. 2 (2017): 145-65. For contemporary critiques about "precarity," see Guy Standing, The Precariat: The New Dangerous Class (London, 2011); Colin Crouch, Will the Gig Economy Prevail? (Cambridge, 2019). Low pay and insecurity were central concerns of the independent review of employment practices commissioned by Prime Minister Theresa May in October 2016: Matthew Taylor, Good Work: The Taylor Review of Modern Working Practices (London, 2017) (the report was updated in May 2018: Gov.uk (website), https:/www.gov.uk/government/publications/good-work-the-taylor-review-ofmodern-working-practices.

${ }^{10}$ In using this terminology, I follow Guy Ortolano, who defines social democracy as an ideological formation that "aimed to reduce collective inequality by removing aspects of social and economic life from the market" and market liberalism as one that "aimed to increase individual freedom by removing aspects of social and economic life from the state." Guy Ortolano, Thatcher's Progress: From Social Democracy to Market Liberalism through an English New Town (Cambridge, 2019), 17. See also James Vernon, Modern Britain: 1750 to the Present (Cambridge, 2017), parts 4 and 5. 
achievement of the mid-twentieth century, when most Western democracies enshrined workers' rights to union membership, protection against dismissal, and other entitlements including sick pay, paid holiday, and parental leave. ${ }^{11}$ In Britain, these rights were codified in the Employment Act of 1975, which had barely reached the statute book before coming under attack from Thatcher's crusade to deregulate markets, unleash enterprise, and create a more flexible workforce. By the 1990s, flexibility had become the primary goal of labor market policies across Western economies, clearing the way for a further proliferation of nonstandard forms of employment, including temporary, agency, and part-time work, freelancing, "gig" work, and zero-hour contracts. As a term, "flexibility" acquired its dual contemporary meaning in these years: of deregulation and lower social protections on the one hand, and of greater choice and diversity of working patterns on the other. ${ }^{12}$

The political battles over homework can be mapped onto this trajectory. As the analysis below reveals, opponents of intervention to regulate homework framed their arguments through a New Right lens of enterprise culture and free-market individualism. Homeworkers, they claimed, were not exploited victims but economic agents grasping opportunities to earn in ways that suited their convenience. Ranged against them stood an alliance of trade unionists, low-pay campaigners, and community activists who clamored for homeworkers' employment rights and —reflecting socialist-feminist influences-for public investment in childcare to give women a genuine choice between working at home or outside it. Despite persistent campaigning by these groups, the policies of John Major's Conservative governments (1990-1997) and the New Labour governments (1997-2010) did little to challenge the consensus around flexible labor markets in general or to improve the status of homeworkers in particular, with the partial exception of the National Minimum Wage. When the International Labour Organisation passed a convention on homework in 1996, Britain did not sign it, and has not signed it still. ${ }^{13}$ The struggle over homework thus lends support to the claim that labor market deregulation represented one of neoliberalism's enduring successes. ${ }^{14}$

Yet while this broad metanarrative has much to recommend it, it tells only part of the story. Ideological change takes place in historically specific contexts and through particular processes, which it is the historian's task to capture and account for. As Guy Ortolano has recently argued of this period, "historians must attend not only to the dominant ideological formation at century's end-its origins and triumph-but also to foreclosed efforts to sustain an alternative settlement." 15 The struggle over regulating homework played out during a long moment of transition for Britain's

${ }^{11}$ Crouch, Will the Gig Economy Prevail?, chap. 3.

12 Paul Davies and Mark Freedland, Towards a Flexible Labour Market: Labour Legislation and Regulation since the 1990s (Oxford, 2007); Werner Eichhorst and Paul Marx, eds., Non-standard Employment in PostIndustrial Labour Markets: An Occupational Perspective (Cheltenham, 2015)

${ }^{13}$ I do not deal here with debates over the regulation of homework in the intergovernmental arena; for discussion of these debates, see Elisabeth Prügl, The Global Construction of Gender: Home-Based Work in the Political Economy of the 20th Century (New York, 1999); and Eileen Boris, Making the Woman Worker: Precarious Labor and the Fight for Global Standards, 1919-2019 (Oxford, 2019), esp. chap. 5.

${ }^{14}$ It was a success compared, for instance, to efforts to contain welfare spending or curb expansionary fiscal policies. See discussion in Jim Tomlinson, "De-industrialization: Strengths and Weaknesses as a Key Concept for Understanding Post-war British History," Urban History 47, no. 2 (2020): 199-219, at 212.

${ }^{15}$ Ortolano, Thatcher's Progress, 21. 
economy, as its traditional manufacturing base gave way to an expanding service sector and new forms of decentralized production. The resurgence of low-paid homework in Britain's clothing industries took place alongside the emergence of a new global division of labor, with multinationals increasingly outsourcing production overseas. One campaigner, the radical economist Swasti Mitter, spoke of “"Third World' enclaves" forming in the West. ${ }^{16}$ But one further facet of this structural shift was the appearance of a very different kind of home-based work among managers, professionals, and small-business owners, often enabled by cutting-edge information and communication technologies. "Telework," as it was initially called, rolled out gradually and unevenly before expanding more rapidly from the late 1990s, reflecting rising levels of personal computer ownership and wider household access to broadband internet services. It is this form of homework that was widely adopted by white-collar workers during the Covid-19 pandemic, which reached Britain in February 2020 (and is ongoing at the time of writing). ${ }^{17}$

These developments did not carry any intrinsic ideological significance and belonged to much longer-term processes of deindustrialization and office automation. ${ }^{18}$ Yet the growth in white-collar homework in the 1980s was interpreted by Conservative politicians and officials in such a way as to delegitimize the case for stronger statutory regulation of homework. In arguing against intervention, these actors drew on new data sources that seemed to point to a future of safe, wellpaid, and congenial home-based work rather than the sweatshops of their opponents' imagining. By contrast, the more worrying picture suggested by the research of campaigners carried little weight with policy makers. Arguably most consequential of all was the failure of the modernizing left to bring "old" and "new" forms of homework into the same interpretive frame. The structural similarities between Victorian-style sweated labor and the emerging world of telework, freelancing, and self-employment were overlooked amid the intellectual excitement generated by Britain's transition toward postindustrial modernity. This techno-optimism, I argue, helps to explain why New Labour, once in office, and especially when less benign economic conditions set in after 2008, lacked the tools to rearticulate the case for enriched employment rights-for homeworkers or for anybody else.

In short, we need to provide a space for agency and contingency in the evolution of public policy toward homework rather than viewing it, as Susan Pedersen has written of an earlier episode in British social policy, as "the inexorable working out of

\footnotetext{
${ }^{16}$ Swasti Mitter, quoted in Report of the National Homeworking Conference 1985 (London, 1985), 6; copy in records of the Greater London Council, GLC/DG/PUB/01/190/U0477, London Metropolitan Archives.

${ }^{17}$ According to one study, 29.5 percent of those in employment before the Covid-19 lockdown worked at home (5.7 percent exclusively, 6.1 percent often, and 17.7 percent sometimes), with the highest levels recorded among those with degree-level qualifications. In April 2020, after the national lockdown was introduced, 43.1 percent of those in employment were working exclusively at home. Among those with graduate-level qualifications, the figure was 64.4 percent. Alan Felstead and Darja Reuschke, Homeworking in the UK: Before and during the 2020 Lockdown, Wales Institute of Social and Economic Research report (Cardiff, 2020).

18 Tomlinson, "De-industrialization"; see also Jim Tomlinson, "De-industrialization Not Decline: A New Meta-narrative for Post-war British History," Twentieth Century British History 27, no. 1 (2016): 76-99. For office automation, see Ursula Huws, Werner B. Korte, and Simon Robinson, Telework: Towards the Elusive Office (Chichester, 1990).
} 
economic forces or institutional trends." 19 The particularities of the British pathway toward flexible labor-market norms are set in even sharper relief when compared to battles over homework in the United States, extensively researched by Eileen Boris. ${ }^{20}$ As I briefly discuss in the final section of the article, the British and American New Right shared much ideological ground in the 1980s, yet the debate over homework played out differently in the two countries. This difference was due to the legacy of earlier measures to prohibit industrial homework in the United States and the creation of an alliance between homeworkers and free-market ideologues, contrasting dramatically with Greater London Council-style community level activism in Britain. These sorts of comparisons, which might be usefully developed and extended, help not only to specify the distinct ideological features of the British debate over homework but also to account more precisely for how labor markets were remade across Western economies in the late twentieth century.

\section{I}

In July 1974, the topic of discussion on Jimmy Young's popular Radio 2 lunchtime show was homework. A representative of the Low Pay Unit, a newly established research and campaigning organization, invited listeners to get in touch if they were currently doing waged work at home, an appeal that produced over a hundred letters. ${ }^{21}$ Around half of these correspondents, all female, went on to supply information for the Low Pay Unit report, Sweated Labour: A Study of Homework, which painted a grim picture of homeworkers' lives. Its author, Marie Brown, detailed the pitifully low piece-rates earned by women for knitting or crocheting garments, making toys, assembling Christmas crackers, and varnishing fishing rods in their homes. Those working full time earned an average of 12.5 pence an hour, less than a quarter of the national average, while only one woman in the sample earned above the minimum set by the Wages Council for her industry. ${ }^{22}$ Many had spent their own money on equipment and materials, in some cases responding to newspaper advertisements promising high earnings "from the comfort of your home." The women were often under dire financial pressure and felt constrained by their caring responsibilities from looking for better-paid work. One woman making soft toys told the Low Pay Unit, "I know I am a fool to do this, but I

\footnotetext{
19 Susan Pedersen, "The Failure of Feminism in the Making of the British Welfare State," Radical History Review, no. 43 (1989): 86-110, at 87.

${ }^{20}$ Eileen Boris, Home to Work: Motherhood and the Politics of Industrial Homework in the United States (Cambridge, 1994).

${ }^{21}$ The Low Pay Unit was founded in 1974 by Frank Field, then director of the Child Poverty Action Group, and David Layton, with financial support from the Rowntree family. Layton was the son of the journalist Walter Layton and founder in 1966 of the influential Incomes Data Services. Its focus was tackling low pay as a key cause of family poverty. Alongside Field, the unit's early core staff included Marie Brown, Steve Winyard, Jill Sullivan, and Chris Pond. See Steve Winyard, Pressure for the Poor: The Poverty Lobby and Policy Making (London, 1987), 45; Frank Field, MP, interview conducted for Economic and Social Research Council project Poverty in the UK: Advancing Paradata Analysis and Open Access, 2016 (transcript), https://www.poverty.ac.uk/system/files/video-transcripts/Frank-Field-2-rethinkingpoverty.pdf; Alastair Hatchett, "David Layton Obituary”" Guardian, 29 September 2009, https://www. theguardian.com/politics/2009/sep/29/david-layton-obituary. All references to the Guardian in this article are to the UK edition.

${ }^{22}$ Marie Brown, Sweated Labour: A Study of Homework (London, 1974), 11.
} 
have to work at home and I have no choice but to agree to the boss's terms." 23 Several others described their work as "slave labour."

These accounts of homeworking were reinforced by the findings of subsequent reports and investigations that won media coverage in the left-leaning press and provided ammunition for the Low Pay Unit's allies in Parliament. ${ }^{24}$ Ashley's colleague Frank White, a Labour MP for Bury and Radcliffe, proved an especially faithful advocate, introducing private members bills in 1979 and 1981 and using every opportunity to draw parliamentary attention to the plight of homeworkers. During a 1982 debate on the economic impact of the deepening recession on women, White read out a letter received from a woman in Surrey who described how she had been paid $£ 10$ to produce an intricately designed long-sleeved sweater: "This garment took me a fortnight to do working approximately from 2 pm to $6 \mathrm{pm}$ and $7.30 \mathrm{pm}$ to $11 \mathrm{pm}$, and the payment works out at about 10p per hour (between 98-100 hours). I have arthritis in my feet and legs and cannot go out to work." For White, this was "the unacceptable face of Britain. The lady is crippled with arthritis, cannot secure a job and is working at home for $10 \mathrm{p}$ an hour. It is frightening." 25

Others voices in the debate looked back to the Edwardian agitation against sweating, still in living memory for some. The socialist firebrand Fenner Brockway, now a peer in his late eighties, reminded the Lords chamber that he had "campaigned on behalf of the half-starved homeworkers in poverty in Pentonville, and took a little part, with Mary MacArthur, in securing the establishment of wages councils."26 Ethel Chipchase, secretary of the Trades Union Council Women's Advisory Committee, recalled in an interview with the Guardian that homeworking had been commonplace in Poplar, east London, where she had grown up in the early 1920s: "I remember we had a neighbour who sewed the collars of men's shirts . . I have never forgotten seeing her hard at work, day after day, from eight in the morning until 11 at night." 27 That the bad old days of low pay and sweating were returning for large sections of the British population formed part of a wider narrative of stalled social progress promulgated by antipoverty campaigners in the late 1960s and 1970 s. ${ }^{28}$

One distinguishing feature of the late twentieth-century debate concerned the position of the trade unions. In the Edwardian campaign against sweating, the bulk of the labor movement had regarded homeworking women as a threat to male wage bargaining and a permanent source of blackleg labor. This attitude

${ }^{23}$ Brown, Sweated Labour: A Study of Homework, 8.

${ }^{24}$ See, for instance, Brian Bolton, An End to Homeworking (London, 1975); Simon Crine, The Hidden Army (London, 1979). For press coverage, see Marie Brown, "Cracker Trap," Guardian, 19 December 1974, 11; "Homeworker Paid lp an Hour," Guardian, 7 December 1976, 8; "Home Toy Makers Get a Raw Deal on Wages Says ACAS," Guardian, 20 September 1978, 4; New Society, 2 February 1978, 257.

25 "The Economy (Impact on Women)," Parliamentary Debates, House of Commons, 8 December 1982, 6th ser., vol. 33, col. 861-930, at 888.

26 "Homeworkers' Payments," Parliamentary Debates, House of Lords, 18 July 1978, 5th ser., vol. 395, cols. 146-49, at 147.

${ }^{27}$ Mary Edwards, "Cracker Trap," Guardian, 10 January 1975, 11.

${ }^{28}$ Tanya Evans, "Stopping the Poor Getting Poorer: The Establishment and Professionalisation of Poverty NGOs, 1945-95," in NGOs in Contemporary Britain: Non-state Actors in Society and Politics since 1945, ed. Nick Crowson, Matthew Hilton, and James McKay (Basingstoke, 2009), 147-63. 
persisted through the interwar and postwar decades. Trade unionists were suspicious of government moves to recruit homeworkers to essential industries during the Second World War and again during the exports drive of the late 1940s. Florence Hancock, then president of the Trades Union Congress, expressed her hostility toward official homework schemes to the Ministry of Labour in November 1947, pointing to the difficulty of exerting control over conditions and pay. ${ }^{29}$ Little practical effort was made to reach out to homeworkers before the late 1960s, when the Women's Advisory Committee passed a resolution calling for statutory measures to protect this section of the workforce against underpayment, poor conditions, and the risk of accidents. This internal pressure prompted the Trades Union Congress's General Council to investigate homework in industries covered by union agreements and to lobby government for action on health and safety. ${ }^{30}$ This activism continued into the 1970s, when the Trades Union Congress argued for special provisions to include homeworkers in the Employment Protection Bill, supported cases of false self-employment taken to industrial tribunals, and set up a working party that drafted the landmark Statement on Homeworking, published in 1978. ${ }^{31}$ This document encouraged unions to recruit homeworkers and showcased local successes, such as Helen Eadie's establishment of a homeworkers' branch of the General and Municipal Workers Union in Torrington, Devon. ${ }^{32}$ Organizing homeworkers did not, by any means, become a pressing priority for the movement as a whole, but it shifted decisively onto the agenda for unions covering industries where homework was common. ${ }^{33}$

Another striking feature of homework campaigning during these years was the combined influence of community-level activism and the rejuvenated women's movement. Feminists had played a prominent part in the Edwardian agitation, with some efforts made by trade unionists such as Mary Macarthur to organize homeworkers in particular trades. Yet the dominant position adopted by these mostly middle-class reformers was that homeworkers were helpless victims in need of statutory protection. ${ }^{34}$ By contrast, women's agency and voice were central to the campaigns of the later twentieth century. Grassroots organizations sprang up in London, Leicester, West Yorkshire, and Nottingham over the course of the late 1970s and 1980s, supplying legal advice and putting homeworkers in touch with each other. ${ }^{35}$ The Leicester Outworkers Campaign began in 1979 when a group of student community workers persuaded the council to post a "fact pack" to five

${ }^{29}$ Minutes of the Ministry of Labour Women's Consultative Committee, 19 November 1947, ML 28/ 633, The National Archives (hereafter this repository is abbreviated as TNA).

${ }^{30}$ Women Workers 1969 (Report for 1968-69 of the Trades Union Congress Women's Advisory Committee), 29, 113-14.

${ }^{31}$ Edwards, "Cracker Trap"; "Homeworkers" (Oral questions), Parliamentary Debates, House of Commons, 18 February 1975, 5th ser., vol. 886, cols. 1096-97; Bolton, An End to Homeworking, 10.

32 Trades Union Congress, Statement on Homeworking (1978), 33-34.

33 The Trades Union Congress's Working Party consisted of members of its Women's Advisory Committee, the Transport and General Workers Union, the National Union of Dyers, Bleachers and Textiles Workers, National Union of Hosiery and Knitwear Workers, Rossendale Union, General and Municipal Workers Union, and the National Union of Tailors and Garment Workers. See also Wilding, "Organising Homeworkers," chap. 7.

34 Thom, "Free from Chains?"; McCarthy, Double Lives, 51-52, 58-62.

35 Wilding, "Organising Homeworkers," 70. 
hundred officially registered homeworkers, of whom around a hundred responded to their appeal to get in touch. ${ }^{36}$ As a campaign spokeswoman told a conference in 1985, "It has enabled us to find out a lot more about what outworkers themselves want. It isn't, as yet, organizing, but it is trying to feed the view of outworkers themselves into what the campaign is doing." 37 These efforts were assisted by a flurry of ethnographic research projects carried out by feminist researchers-including the sociologist Sheila Allen in West Yorkshire and Swasti Mitter in East London-who sought to build trust with their subjects and encouraged them to describe their experiences in their own words. ${ }^{38}$

Feminist photography and imagery brought further visibility to homework, contributing to the wider flourishing of artistic creativity within the 1970s women's movement. ${ }^{39}$ Some of this imagery recalled Edwardian anti-sweating propaganda but eschewed its voyeuristic and sensationalist tone. ${ }^{40}$ Margaret Harrison's 1977 multimedia collage, Homeworkers, emerged from two years of conversation and contact with Mrs. McGilvrey, a homeworker whom the artist met while working with the National Campaign for Homeworkers and Helen Eadie. ${ }^{41}$ Gina Glover helped to found the Wandsworth Photo Co-op in 1979 as a radical collective whose documentary-style photography was widely used by trade unions and leftleaning councils, including the Women's Committee of the Greater London Council. ${ }^{42}$ As well as producing images of nurses, cleaners, and dinner ladies, Glover photographed a neighbor assembling small electrical components in her front room, a child's face peering over the tabletop. Glover's colleague Janis Austen photographed a mother seated behind an industrial-sized sewing machine, her little son waving at the camera from his baby walker. Their purpose, Glover recalled, was to create images that had a "wider social purpose" and contributed to "the social good." 43

\footnotetext{
36 "Memorandum submitted by the Leicester Outwork Campaign," in Minutes of Evidence for 19 May 1981 (appendices), Select Committee on Employment, Session 1980-1981, "Homeworking."

${ }^{37}$ Mary Hopkins as recorded in Report of the National Homeworking Conference 1985, 14.

${ }^{38}$ Sheila Allen and Carol Wolkowitz, "Homeworking and the Control of Women's Work," in Waged Work: A Reader (London, 1986), 238-64; Sheila Allen and Carol Wolkowitz, Homeworking: Myths and Realities (London, 1987); Swasti Mitter, "Industrial Restructuring and Manufacturing Homework: Immigrant Women in the UK Clothing Industry," Capital and Class, no. 27 (1985): 37-80.

${ }^{39}$ Josie McLellan, "From the Political to the Personal: Work and Class in 1970s British Feminist Art," Twentieth Century British History 31, no. 2 (2020): 252-74.

${ }^{40}$ For earlier imagery, see Huneault, Difficult Subjects, chap. 5.

${ }^{41}$ Harrison founded the Women's Liberation Art Group in 1970 and, according to a recent interview, met McGilvrey in her home where she was assembling tax forms for the Inland Revenue: “The worker's house was absolutely crammed from top to bottom. She had two young children and I think she had separated from her husband. This was the only work she could do. There was hardly any childcare available at that time." Anna McNay, "Margaret Harrison: 'You Have to Have a Strategy to Draw People into the Work," Studio International, 1 June 2016, https://www.studiointernational.com/index.php/margaret-harrison-interview-accumulations-middlesbrough-institute-of-modern-art. For photographs of McGilvrey, see "Margaret Harrison: Feminism, Irony, and Women's Rights, Kahn Academy (website), n.d., accessed 10 September 2021, https:/www.khanacademy.org/partner-content/tate/women-in-art/womens-issuesin-art/v/margaret-harrison.

${ }^{42}$ It was later renamed Photo Co-op and then subsequently became Photofusion. See Gina Glover, Investigations 1: Social Action (2017), 9-10, https://staticl.squarespace.com/static/57876e45414fb50d7405fl0c/t/ 5a0079ele2c4839469463744/1509980703346/Gina_Glover_Social_Action.pdf.

${ }^{43}$ Glover, Investigations 1.
} 
Women from South Asian migrant communities featured especially prominently in this activism and research. Homeworkers were widely employed in the clothing industries of Coventry, Leicester, Leeds, and Tower Hamlets, where, from the 1970s, male migrants established small businesses supplying large retail clothing chains. ${ }^{44}$ Mitter observed that "access to cheap female labour, normally at extremely low rates of pay, is often the only advantage these employers have over their white counterparts," although white business owners also sought out South Asian women, whom they viewed as a cheap, docile labor force. ${ }^{45}$ For women with caring responsibilities, poor English skills, and husbands who wished to keep their wives and daughters semi-secluded, homework was often the only viable option for wage earning. In a hostile host country, it offered additional advantages. As an organizer from the Greenwich Homeworkers Project explained, her members "feel at home, they're not in a strange factory with an interfering supervisor, they don't have to ask permission to go to the loo, they don't have to work with racist white women, they can eat their own food without feeling embarrassed." 46 Activists worked hard to make contact with these groups, publishing leaflets in multiple languages, organizing home visits, information sessions, and group excursions and collaborating closely with the small number of homeworking officers appointed by local councils. ${ }^{47}$

These combined forces-trade unionism, community organizing, feminism, and anti-racism-came together with great effect at the Labour-controlled Greater London Council between 1981 and its abolition in 1986. The council adopted a code of best practice concerning the employment of homeworkers on council contracts and in 1985 hosted a National Conference on Homeworking. ${ }^{48}$ This event brought together homeworking activists, trade unionists, researchers, and local authority officials and resulted in the creation of the National Group on Homeworking and the adoption of a homeworkers' charter. This called for a national minimum wage, employee status for all homeworkers, strengthened health and safety protections, training opportunities and childcare provision, and an "end to racist and sexist practices. $" 49$

The Greater London Council integrated these demands into its 1985 London Industrial Strategy, which included an entire chapter on homeworkers and drew heavily on Mitter's research on the clothing industries. The strategy noted the pressures and constraints pushing women into low-paid homework, including lack of childcare, disabilities, and racism in the workplace. It committed the council to action in the short term to improve homeworkers' pay and conditions, alongside a

\footnotetext{
${ }^{44}$ Samir Shah, Immigrants and Employment in the Clothing Industry: The Rag Trade in London's East End (London, 1975); Barbro Hoel, "Contemporary Clothing Sweatshops," in Work, Women and the Labour Market, ed. Jackie West (London, 1982), 80-98

${ }^{45}$ Mitter, "Industrial Restructuring," 59.

${ }^{46}$ Ravi Randhana, in Report of the National Homeworking Conference 1985, 15.

${ }^{47}$ In 1979, Hackney council became first in the United Kingdom to appoint a homeworking officer. See Wilding, "Organising Homeworkers," 70-79; for projects with the Cypriot community in north London, see Flora Anthias, "Sexual Divisions and Ethnic Adaptation: The Case of Greek-Cypriot Women," in One Way Ticket: Migration and Female Labour, ed. Annie Phizacklea (London, 1983), 73-94.

${ }_{48}$ Press release, "A New Deal for Homeworkers," dated 22 March 1982, GLC/DG/PRB/35/038/098, London Metropolitan Archives.

${ }^{49}$ National Conference on Homeworking 1985, appendix.
} 
long-term strategy to make alternative work possible for women. One initiative already underway offered training for Asian and Cypriot homeworkers in the clothing sector who wished to set up their own workshops or cooperatives. ${ }^{50}$ The council then pledged to offer childcare facilities to help homeworkers with small children attend these training sessions, a commitment that fed its wider efforts to extend nursery provision through making grants to local childcare centers. ${ }^{51}$ One homeworker from Southwark neatly summarized what was needed in her address to the 1985 conference: "Our demands are to be paid a decent wage, with more childcare facilities. We are asking for recognition of our labour and sweat. We need support from trade unions and other workers and the Labour Party can fight for us. Black Women's Rights. There ought today to be a start for a national campaign based on our demands." $" 52$

\section{II}

This exceptionally rich picture of community and local government activism was not matched at the level of national policy. The Labour governments of 1975-1979 were broadly sympathetic to the plight of homeworkers and conscious of the publicity that bodies like the Low Pay Unit were able to generate. ${ }^{53}$ Yet ministers took only limited steps, focusing on the enforcement of minimum rates in Wages Council industries and stricter observation of health and safety laws, both areas already identified by officials as requiring attention. ${ }^{54}$ In July 1978, the government established a Homeworking Unit within the Wages Inspectorate with a remit to investigate pay and monitor record keeping by employers. ${ }^{55}$ This step was followed by the convening of an Advisory Committee on Homeworking with members drawn from both sides of industry. ${ }^{56}$ Responding to Jack Ashley in Parliament in February 1978, the junior minister John Grant offered reassurances that the government was not

${ }^{50}$ London Industrial Strategy: Homeworking (London, 1985), 27.

${ }^{51}$ As Stephen Brooke notes, 60 percent of the Greater London Council Women's Committee's budget was spent on funding such centers in 1984, and by 1986, the GLC funded 12 percent of all full-time childcare places in London. Stephen Brooke, "Space, Emotions and the Everyday: The Affective Ecology of 1980s London," Twentieth Century British History 28, no. 1 (2017): 110-42.

${ }^{52}$ National Conference on Homeworking, 16.

${ }^{53}$ Various miscellaneous clippings, LAB 112/106, TNA.

${ }^{54}$ See David Brown to Mr. Allison, 8 February 1978, who refers to the recommendation that the Department of Employment undertake an inquiry into homeworking made by the Sub-Committee of the House of Commons Select Committee on Expenditure in 1973, and to two reports by the Commission on Industrial Relations, Pin, Hook and Eye and Snap Fastener Wages Council (1973) and Clothing Wages Council (1974), which questioned the adequacy of the Wages Council regulations in protecting homeworkers' pay, LAB 112/106, TNA. In 1978, Wages Council inspectors carried out a "special drive" to monitor homeworkers' pay in parts of London and Birmingham. See minutes of the first meeting of the Department of Employment Advisory Committee on Homeworking, 10 October 1978, included in memorandum submitted by the Department to the Select Committee on Employment's enquiry into homeworking in 1981, Appendices to the Minutes of Evidence Taken before the Employment Committee (London, 1981), 145-47.

55 As announced by John Grant to the House of Commons (Written Answers), 5 July 1978, 5th ser., vol. 953, cols. 186-87W.

${ }^{56}$ The committee was chaired by Grant and met twice, on 10 October 1978 and 24 January 1979. It was scheduled to meet on 9 May, but this was called off due to the general election. The minutes are included in the appendices of the Select Committee on Employment's 1980-81 inquiry. Miscellaneous clippings, LAB 
ruling anything out in legislative terms and was "genuinely anxious to make progress." Yet he also warned that ceding the Trades Union Congress's demand for union access to local authority lists of homeworkers was likely to prove controversial and that giving all homeworkers employee status "would conflict with the common law of contract." 57

Nor was there enthusiasm for establishing a national minimum wage or even a statutory minimum for homeworkers. Labour's spokesman in the Lords, Lord Wallace, clarified that, with the exception of those covered by an existing Wages Council order, homeworkers' pay remained "a matter for agreement between the workers and the employer or their respective representatives, as it is for any other worker. . In either case the Government have no power to intervene in the wages-fixing process." 58 This stance spoke in part to the deeply engrained tendency among British trade unionists to favor voluntary collective bargaining over statutory regulation, and in part to the Labour party's growing disenchantment with the Wages Council machinery, which, the party feared, was exerting a downward pressure on wages and discouraging union membership. ${ }^{59}$ Several Low Pay Unit sources suggest that Callaghan's government was, in fact, preparing to introduce its own Homeworkers Protection Bill by April 1979, but the degree of commitment on the part of ministers is not clear from the archival record. ${ }^{60}$

What is clear, however, is that after the Conservatives returned to power the following month, whatever momentum existed for legislative action stalled almost completely. The Advisory Committee on Homeworking was suspended, and ministers were dismissive of recommendations made by the Commons Select Committee on Employment following a special enquiry conducted in 1981. The rationale behind the establishment of this parliamentary enquiry into homeworking is obscure, but it seems likely that the impetus was provided by the Labour MPs on the committee, nearly all of whom had trade unionist backgrounds, including the chair, John Golding, MP for Newcastle-under-Lyme and a former employment minister. ${ }^{61}$

112/106, TNA; Appendices to the Minutes of Evidence Taken before the Employment Committee (London, 1981)

57 "Homeworkers," Parliamentary Debates, House of Commons, 9 February 1978, 5th ser., vol. 943 , cols. 1812-22, at 1821 .

58 "Homeworkers' Payments," Parliamentary Debates, House of Lords, 18 July 1978, 5th ser., vol. 395, cols. 146-49, at 147 .

${ }^{59}$ Blackburn, Fair Day's Wage, chap. 7; Jerold L. Waltman, Minimum Wage Policy in Great Britain and the United States (New York, 2008).

${ }^{60}$ The claim is made by Crine in The Hidden Army, chap. 1, and repeated by Liz Bisset and Ursula Huws in Sweated Labour: Homeworking in Britain Today (London, 1984). The minutes of the Homeworking Advisory Committee for 24 January 1979 state that discussions with the Confederation of British Industry and Trades Union Congress on the issue of employment status were underway, but I have found no evidence of a bill being drafted or planned. Speaking at the Greater London Council Homeworking conference in 1985, Tess Gill argued that the "homeworking lobby" was not well organized during the 1974-1979 Labour government and failed to make protection for homeworkers integral to the employment protection acts of 1974, 1975, and 1979. (See National Conference on Homeworking, 10.)

${ }^{61}$ Although Conservatives outnumbered Labour five to four, the only Conservative MP who consistently attended the sessions of evidence was Michael Colvin. According to a Guardian profile in 2000, Colvin was considered a "wet," which in the Thatcherite terminology of the 1980s meant that he was positioned on the left of the party, especially in relation to social policy ("The Guardian Profile: Michael Colvin," Guardian, 24 February 2000, https:/www.theguardian.com/uk/2000/feb/24/guardianprofiles). 
The committee's proceedings are highly revealing of the ideological cleavages emerging within the debate over homework by the early 1980s. On one side were the campaigners demanding stronger protections, and on the other their opponents in business and industry arguing against burdensome regulations. Appearing in person before the committee, Frank White again described the pressures pushing vulnerable groups into homework, from caring responsibilities and poor health to the cultural and language barriers experienced by recent immigrants: "All are ready prey to people who would seek to exploit them and do exploit them." ${ }^{\prime 2}$ His sentiments were echoed in the testimony of trade unionists, including the witness from the National Union of Hosiery and Knitwear Workers who described homeworkers as "ripe for any kind of commercial exploitation; and that is why they suffer. They are in such a weak position they cannot protect themselves."63 These claims were further amplified in written evidence submitted by the Low Pay Unit and the Leicester Outwork Campaign, while other witnesses described how lack of childcare facilities left many women with no choice but to earn at home. The homeworking officer from Leicester City Council confirmed that the women he talked to would prefer alternative employment, were childcare available: "Yes indeed, they do say we need to work for the extra income, and we would like to work outside the home. We realise in some cases that we are not paid as much as factory workers, and they just need to work for that extra income and would work outside, if there were adequate chances."64

Pressing a very different case were the representatives of the Confederation of British Industry. They challenged the claim that homeworkers were vulnerable to exploitation and noted instead the advantages that this kind of employment offered: "There are no set hours so that they can arrange their work to suit their own convenience [and] the saving of time and expense on travelling can be considerable." 65 In his remarks to the committee, J. R. Wilson, a clothing manufacturer, suggested that this flexibility disqualified homeworkers from the benefits of full employee status: "To us it seems illogical that people who do take on that particular freedom - and it is in many cases a freedom they choose to have-should also receive the protections that go with the rest of us who sadly have to go to work and work regular hours every day of the week." 66

Homeworkers, he insisted, often preferred to work irregularly and to keep their earnings below the threshold for making national insurance contributions. "They like the opportunity, for instance, in the summer months to go off and dig potatoes

\footnotetext{
The other Labour MPs were Jim Craigen, a Cooperative MP for Glasgow who had previously worked for the Scottish Trades Union Congress; Ray Powell, a Welsh MP and trade unionist; Giles Radice, MP for Chester-le-Street and a former employee of the General and Municipal Workers Union; and Oonagh Macdonald, MP for Thurrock, who replaced Radice in March 1981 and was the only Labour member without a notable trade unionist background.

${ }^{62}$ Select Committee on Employment, Minutes of Evidence, 17 March 1981, 54.

${ }^{63}$ Select Committee on Employment, Minutes of Evidence, 14 April 1981, 92.

${ }^{64}$ Select Committee on Employment, Minutes of Evidence, 28 April 1981, 125.

${ }^{65}$ Memorandum submitted by the Confederation of British Industry Wages Councils (Employers') Consultative Committee, dated 26 November 1980, published in Select Committee on Employment, Minutes of Evidence, 7 April 1981, 58.

${ }^{66}$ Select Committee on Employment, Minutes of Evidence, 7 April 1981, 67.
} 
or tread grapes in France or what have you and they do not like the idea of being tied down to a particular type of job." 67 Written evidence submitted by the company Home Automation Ltd. reinforced this perspective, observing that homework "enables a person at home with young children to use their own job skills," and noting that feedback from their own homeworkers was "very enthusiastic." 68 Representatives from the National Federation of Self-Employed and Small Businesses and the Retail Consortium added warnings that greater regulation would make it harder for businesses to offer this kind of flexible employment to those who wanted to do it. ${ }^{69}$

In its final report, the Select Committee rejected these arguments, expressing skepticism toward claims that homeworkers were rarely under pressure to earn or strongly preferred this type of employment. ${ }^{70}$ The report acknowledged the difficulties of unionization and the constraints preventing women in particular from seeking better-paid work outside the home. It called for greater clarity on the employment status of homeworkers and full rights and protections for those formally employed. The committee did not favor the establishment of a wages council specifically for homeworkers, but it did recommend more frequent inspection, tighter monitoring of health and safety compliance, and the reactivation of the Homeworking Advisory Committee. ${ }^{71}$ Yet in his response, Secretary of State Norman Tebbit largely rejected these proposals. Employment status remained a question for the courts, he argued, while benefit abuse could become a serious problem were all homeworkers to be treated as employed. He saw no purpose in reviving the Homeworking Advisory Committee and suggested that more evidence was needed to justify tightening the rules compelling employers to submit registers of homeworkers to local authorities. $^{72}$

${ }^{67}$ Select Committee on Employment, Minutes of Evidence, 7 April 1981, 67.

${ }^{68}$ Memorandum submitted by Home Automation Ltd. (n.d.), in Select Committee on Employment, Minutes of Evidence, 19 May 1982. The company manufactured dimmer lighting and person detector equipment. See Alan Cawson, Leslie Haddon, and Ian Miles, The Shape of Things to Consume: Delivering Information Technology into the Home (Aldershot, 1995), 90.

${ }^{69}$ Examination of Witnesses: Mr. J. Blundell, Parliamentary Officer, and Mr. J. Woolsgrove, Chairman of the Wages Councils Committee of the National Federation of Self-Employed and Small Businesses, and Memorandum submitted by the Retail Consortium: Wages Councils, in Minutes of Evidence, 7 April 1981.

${ }^{70}$ The MPs were especially scathing toward Wilson's reference to treading grapes:

Mr Craigen: "Anyway, how many people tread grapes in the South of France?

Mr Wilson: "I have not got any statistics."

...

Dr McDonald: "bearing in mind that some of the people employed ... probably are women who are unable to go out to work as easily as they would like because of family responsibilities or children. I must admit, I do not really see them taking off to tread grapes in the South of France very easily either."

Minutes of Evidence, 7 April 1981, 67-68.

${ }^{71}$ House of Commons, First Report from the Employment Committee (Session 1981-2): Homeworking (November 1981).

${ }^{72}$ House of Commons, Third Special Report from the Employment Committee (Session 1981-2): Homeworking, 31 March 1982. 
In some respects, this was a predictable response from a "Thatcherite" minister, Tebbit having replaced the "wet" Jim Prior as secretary of state in September $1981 .^{73} \mathrm{He}$ would soon oversee the passage of the 1982 Employment Act, which dramatically curbed trade union power. ${ }^{74}$ The government's response was very quickly denounced in these terms from the left. In Parliament, White described Tebbit as "oblivious to the needs of homeworkers" and declared that the Department of Employment had given "the green light" to "the spiv and the con man to carry on exploiting homeworkers." 75 The Greater London Council's Industrial Strategy also interpreted Tebbit's stance in ideological terms, arguing that the government "finds that homeworking fulfils many of its ideals . . . [homeworkers] are independent,' 'free' to determine their own pattern of work." In reality, the authors noted, "the conditions endured by both homeworkers and their families make a mockery of this ideal."76

Tebbit's dismissal of the committee's recommendations put paid to any hopes that the Conservative government would act on regulating homework, but it did not deter activists from continuing their grassroots work and building alliances with local government and trade unions. It is thus necessary to ask how the government's case for inaction was sustained through the 1980s and became accepted by New Labour in the 1990s. This rested on two closely related factors. The first was a battle over how homework and the risks that it posed to workers were to be defined and measured. The second was the manner in which the future of homework came to be reimagined in techno-optimistic terms as an exciting feature of the emergent "postindustrial" society.

In his response to the Select Committee's report, Tebbit fell back repeatedly on the claim that more "research" was required before any action could be taken, and here he alluded to studies already underway at the Department for Employment. These were led by principal research officer Dr. Catherine Hakim, who had described to the committee the large-scale survey of homeworking that she was in the midst of conducting. This survey derived its sample from the annual Labour Force Survey, which, in Hakim's view, made her research more reliable than the existing body of scholarship derived from "really very small studies, sometimes carried out by a postgraduate with no more than 20 people." 77 The release of Hakim's findings was delayed due to technical difficulties with the dataset and the report was only published in full in 1987, alongside an article summarizing the research in the Department's Employment Gazette. ${ }^{78}$ Hakim adopted a strikingly revisionist stance in these publications. Her

${ }^{73}$ For Thatcher-era definition of wet, see note 60.

${ }^{74}$ The act outlawed the closed shop and raised the level of compensation for those dismissed from a closed shop factory and made trade unions liable for damages resulting from unlawful action.

75 "The Economy (Impact on Women)," Parliamentary Debates, House of Commons, 8 December 1982 , 6th ser., vol. 33, cols. 861-930, at 888 .

${ }^{76}$ London Industrial Strategy: Homeworking, 22.

77 Select Committee on Employment, Minutes of Evidence, 14. Hakim's survey was based on interviews carried out with about two thousand homeworkers or home-based workers, which were grossed up to obtain national estimates. Hakim was not herself involved with the fieldwork, which was carried out by staff at the Office of Population Censuses and Surveys.

${ }^{78}$ Catherine Hakim, Home-Based Work in Britain: A Report on the 1981 Homeworking Survey and the DE Research Programme on Homework, Department of Employment Research Paper no. 60 (London, 1987); Catherine Hakim, "Homeworking in Britain," Employment Gazette (February 1987): 92-104. Some 
survey, she argued, "overturned the stereotypical images of homework and homeworkers," including that of the woman "tied down by the needs of her family, exploited by her employer and working for low wages on tedious, repetitive tasks."79 Far more numerous, Hakim argued, were white-collar homeworkers, which included those doing "jobs in management and administration, professional jobs, design and artistic work, clerical and secretarial jobs, and small numbers of jobs in selling, hairdressing and catering." 80 Homeworkers, Hakim found, were "more highly qualified than most, in better health than most, more likely to own their own homes, and their usual occupations may be more skilled than is reflected in their homeworking job." 81

How did Hakim come up with a picture of homeworking so radically different from that painted by grassroots activists? In part, the answer lies in how she conceptualized her subject as the "home-based" workforce, a capacious category that included childminders and many forms of self-employment, totaling an estimated 658,250 people. ${ }^{82}$ This demarcation had the effect of bringing large numbers of men into the sample, who were overrepresented among the self-employed, and, as a result, the kinds of workers studied by the Low Pay Unit and grassroots activists shrank in statistical significance. "Manufacturing homework" appeared in a small box on the grid that accompanied Hakim's research paper, representing just 9 percent of the total home-based workforce, an estimated 58,750 workers. From her survey data, Hakim found that the majority of home-based workers worked continuously for the same employer, leading her to suggest that the "casualness" of homework had been exaggerated in other studies. ${ }^{83}$ She also reported that the incidence of work-related accidents or health problems was low. Those doing manual homework were the most likely to have accidents, but Hakim classified these as "trivial," consisting in the main of "cuts, falls, bruises, sprained wrists and similar problems of a short-term nature." 84 Only a third of the women surveyed said that they had no option other than to work at home, while the vast majority of all home-based workers expressed satisfaction with their jobs. Even among manual homeworkers, 89 percent declared themselves satisfied.

These findings certainly were striking, but the emphasis that Hakim gave to them in her general conclusions was misleading in several ways. Other parts of her analysis offered a more nuanced and less rosy picture. For example, she noted that women in the home-based workforce were less likely than men to have continuous employment

preliminary findings were published in Catherine Hakim, "Employers' Use of Homework, Outwork and Freelances," Employment Gazette (April 1984): 144-50. The Employment Gazette had been published by the Department for Employment (previously the Ministry of Labour) since 1893 and purported to disseminate "impartial information and unbiased labour statistics on behalf of the UK government." See Martin Whitfield, "Employment Gazette: A Century of Record," Employment Gazette (May 1993): 177-84, at 177.

${ }^{79}$ Hakim, "Homeworking in Britain," 82.

${ }^{80}$ Hakim, 96.

${ }^{81}$ Hakim, 104

${ }^{82}$ Hakim also noted, but did not include in the survey, 750,000 workers with live-in jobs and a further somewhat ambiguous category of 284,000 workers in "construction, haulage and family members." Home-Based Work in Britain, 11.

${ }^{83}$ Hakim, "Homeworking in Britain," 98.

${ }^{84}$ Hakim, 101. 
or to qualify for work-related benefits and protections, and she agreed that the characteristics of much homework made it difficult for workers to determine their employment status under the current rules. Hakim acknowledged the "stress experienced by women in combining paid work with their domestic and childcare activities, especially when all these activities are confined to the home." 85 She found that only a quarter of those surveyed thought that conditions for homeworkers were satisfactory, and 40 percent wanted to see some kind of legislative reform. She accepted that low-paid manufacturing homework was "rarely a positive choice and preference." 86 Despite her emphasis on the expansion of white-collar work, the photographs accompanying Hakim's article in the Employment Gazette were nearly all of manual homeworkers and included images produced by Glover and Austen for the radical Photo Co-op.

Hakim's broader interpretation of her subject matter, however, reframed the meaning of these images, stripping away the critical feminist perspectives and ethnographic knowledge that they represented. Her motives for doing so are difficult to judge, although her later scholarship offers some context for her intellectual choices. After leaving the civil service in 1989, Hakim became well known for a body of work on "preference theory" an analytical framework that explained gendered employment patterns as resulting from men and women's different orientations toward family and work rather than from discrimination or wider structural inequalities. ${ }^{87}$ This theory attracted much criticism from feminist scholars in the 1990s and early 2000s for its static and simplistic framing of women's preference formation. ${ }^{88}$ Interestingly, their critique echoed concerns voiced by members of the Select Committee back in 1981 when Hakim was asked how her survey would investigate homeworkers' complicated feelings about their jobs as well as their material circumstances. "Many homeworkers," the Conservative MP Michael Colvin suggested, "may be quite prepared to accept what may be an injustice in their particular situation but they may say 'We would rather work this way than not have the work at all." 89 Homework campaigners queried Hakim's findings on similar grounds, defending their small-scale qualitative studies as the most effective method for accessing homeworkers and capturing the complexity of their experience. Swasti Mitter was convinced that Hakim had underestimated the number of homeworkers earning cash in hand in the "unregulated and underground economy" of labor-intensive industries like clothing. ${ }^{90}$ The Greater London Council endorsed Mitter's critique in its Industrial Strategy, noting that local activists had "largely abandoned attempts at quantification, arguing that until a basis of trust can be established

${ }^{85}$ Hakim, 103.

${ }^{86}$ Hakim, 103-4.

${ }^{87}$ Catherine Hakim, "Grateful Slaves and Self-Made Women: Fact and Fantasy in Women's Work Orientations," European Sociological Review 7, no. 2 (1991): 101-21; Catherine Hakim, "Five Feminist Myths about Women's Employment," British Journal of Sociology 46, no. 3 (1995): 429-55; Catherine Hakim, "Why So Many Long to Look after a Home and a Family," Daily Mail (London), 29 March 1996, 14 15; Catherine Hakim, Work-Lifestyle Choices in the 21st Century: Preference Theory (Oxford, 2000).

${ }^{88}$ Irene Bruegel, "Whose Myths Are They Anyway? A Comment," Journal of British Sociology 47, no. 1 (1996): 175-77.

${ }^{89}$ Select Committee on Employment, Minutes of Evidence, 24 February 1981, 19-20.

${ }^{90}$ Mitter, "Industrial Restructuring," 39. 
with homeworkers, allowing them to 'come out' and declare the work they are doing, no accurate counting of their numbers will be possible." $" 91$

In Whitehall and Westminster, however, Hakim's study was widely regarded as the authoritative statement on the scale and character of homeworking in Britain. As early as 1983, an official at the Health and Safety Executive pointed to the Department of Employment's preliminary findings as evidence that "a relatively small and declining number of people are engaged in 'manufacturing-type' homework." $\mathrm{He}$ was skeptical that further research would confirm the claims of the Trades Union Congress and the Low Pay Unit that homeworking posed a serious risk to health and safety. ${ }^{92}$ Four years later, members of the Health and Safety Commission discussed Hakim's Employment Gazette article at length, agreeing on the strength of her findings that no legislative action was currently necessary: "The survey shows that the exploitation associated with homework in the past is no longer prevalent. White collar homework predominates; of the minority of homeworkers engaged in manufacturing few even approximate to the stereotype of the exploited unskilled female worker. No evidence was found that homework involves serious health and safety risks on a significant scale." 93

The research was also cited by ministers in Parliament, either directly or obliquely, to discredit opposition claims that homeworkers were routinely exploited. In 1984, the employment minister John Gummer deflected a question from Labour's Jo Richardson on the topic of homework by insisting that the government was "getting the facts rather than relying on some generalisation of party political comments." ${ }^{94} \mathrm{Six}$ months later, he rebuked Richardson again for making "politically-motivated comments," arguing, "many home workers are well paid for what they do," and appealing to members to "treat the subject with the seriousness that it deserves and act on the research which this Government have done.”95 To borrow Pedersen's phrase from her analysis of an earlier episode in social policy, Hakim's findings, though hotly contested from outside quarters, had acquired in government the status of "social-scientific "truth."'"96

\section{III}

There was one further context that explains why Hakim's research found favor with New Right Conservatives like Tebbit or Gummer. This was not simply because

${ }^{91}$ London Industrial Strategy: Homeworking, 15. Academics in the later 1990s largely endorsed this methodological point, noting the importance of recruiting researchers for doorstep-surveys who reflected the gender and ethnic profile of the local area. See Alan Felstead and Nick Jewson, In Work, at Home: Towards an Understanding of Homeworking (London, 2000), at 9.

${ }^{92}$ K. J. Jordan to P. R. Gordon, 21 November 1983, T 430/192, TNA.

93 "Homeworkers"-Paper Circulated for Discussion by Members of the Health and Safety Commission, dated April 1987, EF 7/2250, TNA.

94 "Homeworking Advisory Committee: Oral Answers to Questions," Parliamentary Debates, House of Commons, 24 January 1984, col. 761.

95 "Oral Answers to Questions," Parliamentary Debates, House of Commons, 31 July 1984, 6th ser., vol. 65, cols. 208-9, at 209.

${ }_{96}$ Pedersen uses this phrase in relation to debates over family allowances in the 1920s, showing how Seebohm Rowntree's questionable measurements of household poverty nonetheless became accepted in government "as the only reasonable basis for policymaking." Pedersen, "The Failure of Feminism," 93. 
Hakim's findings legitimized legislative inaction, but because they situated homework within what might be termed an emerging postindustrial modernity. Soon after the rejection of the Select Committee report, the debate over homework shifted ground, turning away from a preoccupation with Victorian-style sweated labor toward a future-orientated vision of flexibility, entrepreneurship, and technological innovation. This change was signaled very clearly by the much warmer reply that Gummer gave in Parliament to his Conservative colleague, Eric Forth, who asked whether the minister agreed that homeworking was "one of the most promising areas for future employment in Britain, particularly in regard to the development of computer technology, because of the ability of people to work with computers at home?" Gummer enthusiastically assented: "It is, indeed, an area of activity which will grow. Modern technology makes for a very satisfactory extension of it. In my constituency it is a particularly valuable addition to the jobs available." 97

This statement dovetailed with the Thatcher government's wider embrace of information technology as a gateway to much-needed job creation and increased global competitiveness for British industry. As early as December 1980, the head of the Downing Street policy unit was telling the prime minister that "in terms of money and jobs, I[information] T[echnology] is the big growth area for Western economies" and urging that she adopt an "intensely market-orientated, flexible and fastmoving" strategy for supporting the sector. ${ }^{98}$ Thatcher subsequently appointed Kenneth Baker to the post of minister for information technology, convened an Information Technology Advisory Panel of industry experts, and designated 1982 as the Year of Information Technology. At a major speech marking the year (known as IT-82), Thatcher declared that she had "no doubt whatsoever that, in the cut-throat competition of the modern world, Information Technology will mean new wealth and new jobs." What was needed was investment in skills and the unleashing of British ingenuity and entrepreneurship: "The door is wide open for today's technologists to become tomorrow's tycoons." 99

For homeworkers, the advent of a new era of information technology had a twofold impact, creating new jobs in programming and systems analysis, and opening up wider possibilities for moving clerical, professional, and managerial work into the home. Interest in how technology might upend the relationship between home and workplace had formed part of the vision of the postindustrial society conjured by futurologists like Daniel Bell and Alvin Toffler in the 1970s. One hundred technology companies, such as the computer manufacturer International Computers Limited and the software house F International, were early movers in making Bell's "electronic cottages" a reality, at least for a small number of workers linked up through networked computer terminals in their homes. Most

\footnotetext{
97 "Oral Answers to Questions," Parliamentary Debates, House of Commons, 31 July 1984, 6th ser., vol. 65, cols. 208-9, at 209.

98 John Hoskyns to Prime Minister, 16 December 1980, PREM 19/489, TNA.

${ }^{99}$ Margaret Thatcher, Speech opening conference on information technology, Barbican Centre, London, 8 December 1982, Thatcher Archive, accessed 13 August 2021, https://www.margaretthatcher.org/document/105067. Thatcher's information technology program was also integrally linked to the privatization agenda, most strikingly in the case of British Telecom. See Jacob Ward, "Financing the Information Age: London TeleCity, the Legacy of IT-82, and the Selling of British Telecom," Twentieth Century British History 30, no. 3 (2019): 424-46.
} 
employers, however, embarked cautiously upon such "teleworking" schemes, inhibited by the costs of computer hardware and line rental and the need for new systems of management and supervision. The largest rise in work-related use of information technology in the home was undoubtedly among the self-employed, who were increasingly likely to own personal computers as the decade wore on. ${ }^{100}$ In 1997 , the first year for which reliable data is available from the Labour Force Survey, there were 921,000 "teleworkers," defined as those using both a telephone and a computer for home-based work. This group accounted for 40 percent of all homeworkers and 4 percent of the overall workforce. ${ }^{101}$

Although skeptical of Hakim's claims that manufacturing homework was in terminal decline, campaigners on the left did take note of the growth in white-collar homework. In 1984, the Low Pay Unit published The New Homeworkers: New Technology and the Changing Location of White-Collar Work, a study undertaken by Ursula Huws for the Equal Opportunities Commission. Huws had developed an interest in the effects of IT on skills and workplace safety while working in the publishing industry in London in the 1970s, a theme that drew her toward further research on how new technologies were reconfiguring women's jobs. ${ }^{102}$ At this time, Huws recalled, she was reading "every feminist publication I could find" and was especially influenced by the writings of the socialist feminist Sheila Rowbotham. ${ }^{103}$ These helped her to develop an analysis of the structural link between paid work and unpaid domestic labor, which she sought to introduce to the growing debate within academic and trade union circles about the impact of new technologies on skills, wages, and industrial relations.

This history formed the backdrop to Huws's The New Homeworkers study, which drew on survey data from seventy-eight respondents, the majority of them married women with children under five working in the computer industry. Huws found that despite these teleworkers being highly skilled, with substantial professional experience, they were earning lower salaries than their similarly qualified on-site colleagues and were pessimistic about their prospects for promotion. Over half of the sample were self-employed and experienced fluctuations in the flow of work, making it hard to plan their workload. Their career trajectories were deeply marked by gender: most had left on-site jobs after becoming mothers, with a few taking on homework to fit with husbands' hours or with home relocations. No less than three-quarters of the sample cited childcare responsibilities as the main reason for working at home. In Huws's words, "the overwhelming majority of the sample had found themselves working at home, whether by choice or by necessity,

100 Tom Lean, Electronic Dreams: How 1980s Britain Learned to Love the Computer (London, 2016), 81; James Baker and David Geiringer, "Space, Text and Selfhood: Encounters with the Personal Computer in the Mass Observation Project Archive, 1991-2004," Contemporary British History 33, no. 3 (2019): 293312; Jane Wheelock, "Personal Computers and an Institutional Model of the Household," in Consuming Technologies: Media and Information in Domestic Spaces, ed. Roger Silverstone and Eric Hirsch (London, 1992), 97-112.

${ }^{101}$ Yolanda Ruiz and Annette Walling, "Home-Based Working Using Communication Technologies," Labour Market Trends 113, no. 10 (2005): 417-26.

${ }^{102}$ Ursula Huws, "The Fading of the Collective Dream? Reflections on Twenty Years' Research on Information Technology and Women's Employment," in Women Encounter Technology: Changing Patterns of Employment in the Third World, ed. Swasti Mitter and Sheila Rowbotham (London, 1995), 31440.

${ }^{103}$ Huws, "Fading of the Collective Dream?," 319. 
because of their family situations." 104 Isolation was named by 60 percent as the main disadvantage of homeworking, while nearly a third complained of unsocial hours and the encroachment of work on family life. "The tone of many responses," Huws wrote, "is one of resigned good humour, or of making the best of an all-too-imperfect job." "105

Huws's research was significant for two reasons: first, because she rooted her observations in empirical research rather than in futurist forecasting; and second, because she deployed a gender lens in order to identify structural similarities between "old" homeworkers and "new" ones. This latter point was reinforced by a second report published by the Low Pay Unit in 1984, which Huws coauthored with Liz Bisset. Sweated Labour analyzed industrial and white-collar homeworkers together, concluding that while pay and job content varied considerably between the two groups (again, all-female), the resemblances were striking: "In few cases is homeworking a freely-chosen, life-enhancing option. On the contrary, in almost all cases it is a poor alternative to working outside the home, selected only because the homeworker's domestic commitments prevent her from going out to work." 106 The report's front cover placed photographs of two homeworking women side by side: a white teleworker typing on a keyboard with a toddler nearby, and a black garment worker pictured next to a sewing machine.

Unlike Hakim's findings, this perspective did not gain much traction in government. The Equal Opportunities Commission declined to publish the New Homeworkers study - due, Huws suspects, to political pressure, prompting her to offer it to the Low Pay Unit. ${ }^{107}$ The Health and Safety Commission read Sweated Labour alongside Hakim's survey in 1987 but concluded that the problems identified by Huws and Bisset in relation to teleworkers, such as "headaches, eyestrain, backache stress, and depression," fell outside their remit. "While by no means unimportant," the memo argued, "such symptoms appear to arise more from family circumstances and problems than from matters under the employer's control inherent in the work actually put out."108

Given Huws's activist background and socialist-feminist credentials, the coolness of the official response to her work is perhaps not terribly surprising. Of greater significance, however, was the relatively low traction that it gained among grassroots campaigners, who continued to focus their energies on serving the poorest workers rather than taking up the cause of their better-paid white-collar peers. By the early 1990s, local activists had become increasingly reliant on short-term project funding from an array of municipal, philanthropic, and central government sources, which they channeled into delivering advice and advocacy services for homeworkers while strengthening their networks with like-minded organizations overseas. ${ }^{109}$ The National Group on Homeworking was especially active in lobbying

${ }^{104}$ Ursula Huws, The New Homeworkers: New Technology and the Changing Location of White-Collar Work (London, 1984), 30 .

${ }^{105}$ Huws, New Homeworkers, 43.

106 Bisset and Huws, Sweated Labour: Homeworking in Britain Today, 38.

107 Ursula Huws (director of Analytica Social and Economic Research), interview by the author, 17 July 2020.

108 "Homeworkers," April 1987, EF 7/2250, TNA.

109 Wilding, "Organising Homeworkers," chap. 3; Jane Tate, "Making Links: The Growth of Homeworker Networks," in Homeworkers in Global Perspective: Invisible No More, ed. Eileen Boris and Elisabeth Prügl (London, 1996), 273-89. 
Labour and Liberal Democrat politicians in the lead-up to the 1997 general election, rearticulating long-standing demands for a minimum wage, formalized employment status, and better health and safety protections. This lobbying produced some modest results following New Labour's victory, including a right to union representation at disciplinary and grievance hearings, a clampdown on fraudulent homeworking scams, and special provisions for homeworkers in the National Minimum Wage legislation, although campaigners found uneven evidence of enforcement of the latter. ${ }^{110}$

This campaigning work was crucial for keeping the needs of low-paid homeworkers on the agenda of politicians. Yet the bifurcation-in conceptual and organizational terms - of "old" and "new" forms of homeworking proved politically consequential. Its effects can be seen from the late 1980s among what might be called the "modernizing left" - the network of individuals, publications, and think tanks whose ideas would help shape New Labour's program in government. One important node in this network was the political magazine Marxism Today, which published an influential manifesto in 1988 entitled "New Times." This document distilled many of the ideas previously showcased in the magazine by such figures as Stuart Hall, Charles Leadbeater, Robin Murray, and Geoff Mulgan, the last of whom cofounded the think tank Demos in 1993 and was subsequently recruited to head Tony Blair's Downing Street Policy Unit. ${ }^{111}$ Key to the "New Times" analysis was the shift taking place in Western, capitalist societies "from the old mass-production Fordist economy to a new, more flexible post-Fordist order based on computers, information technology and robotics." As the authors saw it, this transition toward a postindustrial future was already changing the face of politics, consumption, and work, with its chief features "flexibility, diversity, differentiation, mobility, communication, decentralisation and internationalisation." 112 Of the key voices behind the manifesto, Leadbeater had the strongest interest in the future of work, having co-written with John Lloyd (then editor of the political weekly New Statesman) a major report on this subject for the Financial Times. Their report discussed the impact of new technologies at length, including the "exciting possibilities" of office automation. "Desk-top computers, linked by a telecommunications infrastructure, could allow much work to be done away from the office," Leadbeater and Lloyd wrote. "Homeworking could grow significantly in the future, as employers turn to homeworking to cut the overhead costs of large office premises and to allow more flexible management of working time." 113

With advances in personal computing, rising mobile-phone usage, and the growth of the internet, interest in how new technologies were redesigning jobs and labor markets ran high within center-left circles by the late 1990s. Demos published numerous reports on this theme, exploring the disruption of traditional career structures, the growth of self-employment and small business start-ups, the implications

\footnotetext{
${ }^{110}$ Wilding, "Organising Homeworkers," chaps. 4, 6. See also Jason Heyes and Alex Gray, "Homeworkers and the National Minimum Wage: Evidence from the Textiles and Clothing Industry," Work, Employment and Society 15, no. 4 (2001): 863-73.

${ }^{111}$ Alexandre Campsie, "'Socialism Will Never Be the Same Again': Reimagining British Left-Wing Ideas for the New Times," Contemporary British History 31, no. 2 (2017): 166-88.

112 "New Times," editorial, Marxism Today, October 1988, 3.

113 Charles Leadbeater and John Lloyd, In Search of Work (London, 1987), 98.
} 
of the dot.com boom, and the problems of building and regulating the digital economy. ${ }^{114}$ Like the "New Times" manifesto, these publications had little to say about the kinds of homeworkers who had been organizing and campaigning around low pay and employment rights since the 1970s. Nor did center-left modernizers engage with the work of Ursula Huws, whose expertise on teleworking and automation grew further from the mid-1980s as she joined an expanding international network of researchers working for a range of corporate and not-for-profit funders, including the European Commission and the International Labour Organization. ${ }^{115}$ Huws speculates that her socialist-feminist politics put her at odds with the centrist tendencies of Labour modernizers, reinforced by a more general culture of sexism on the left. ${ }^{116}$ If Mulgan, Leadbeater, and others were broadly optimistic about new technologies and the future of work, Huws took a more skeptical line, warning of rising precarity and casualization and the deepening of existing sexual divisions in the labor market. ${ }^{117}$

This discussion of where homework was positioned in late twentieth century debates about socialist renewal is far from exhaustive, but it is indicative of the wider intellectual excitement that Britain's journey into postindustrial modernity generated on the left. As Alex Campsie has observed, New Times thinkers tended to fetishize novelty, placing great significance on emergent urban lifestyles, from cutting-edge design and satellite television to "trendy" café culture and personal gyms. ${ }^{118}$ Their sense of possibility about how new technologies might unleash choice and autonomy in the domain of work belongs to this vision of individualized subjects leading social change through shifting tastes and everyday practices. Further research is needed to map the trajectories of leftist thinking about information technology more precisely, together with its influence upon New Labour in government. James Baker and David Geiringer suggest that New Labour's "e-futurism" set an important tone in the 1990s and early 2000s, promoting the message that "a wealthy, optimistic UK was to be networked and computationally astute."l19

\footnotetext{
${ }^{114}$ For example, Geoff Mulgan and Ivan Briscoe, The Society of Networks: A New Model for the Information Superhighway and the Communications Supermarket (London, 1995); Fernando Flores and John Gray, Entrepreneurship and the Wired Life: Work in the Wake of Career (London, 2000); Charles Leadbeater and Kate Oakley, Surfing the Long Wave: Knowledge Entrepreneurship in Britain (London, 2001); James Wilsdon and Daniel Stedman Jones, The Politics of Bandwidth: Network Innovation and Regulation in Broadband Britain (London, 2002).

${ }^{115}$ Huws, interview; see also Huws, Korte, and Robinson, Telework. The development of international networks of interest and expertise on teleworking is under-researched, but see Huws's brief survey in 1990 as referenced in Huws, Korte, and Robinson, Telework, xiii. An important milestone was the publication of Europe and the Global Information Society (the Bangemann Report) by the European Commission in 1994. For an indication of the International Labour Organization's growing interest, see the articles in "Information Technology: Bridging the Digital Divide," special issue of World of Work: The Magazine of the ILO, no. 38 (2001)

${ }^{116}$ Huws, interview. Others commented on the "lad culture" that pervaded New Labour; see, for example, the commentary by Helen Wilkinson, who worked closely with Mulgan and others at Demos, in "The Day I Fell out of Love with Blair," New Statesman, 7 August 1998, 9-10.

${ }^{117}$ Ursula Huws, Your Job in the '80s: A Woman's Guide to New Technology (Leeds, 1982); Ursula Huws, "Danger: Women at Work," New Statesman, 17 March 1989, 12-13. For other feminist perspectives, see Cynthia Cockburn, Brothers: Male Dominance and Technological Change (London, 1983); Janine Morgall, "New Office Technology," in Waged Work: A Virago Reader (London, 1986), 114-28.

118 Campsie, "Socialism Will Never Be the Same."

119 Baker and Geiringer, "Space, Text and Selfhood," 295.
} 
Setting these trajectories alongside the history of homework helps to illuminate an important corollary of New Labour's vision, namely, a weakened commitment to enhanced employment rights and an accommodation of flexible labor-market norms. New technologies did not drive the party's shift away from older, solidaristic models of social democracy, but Labour did come to assimilate a large part of the right's belief in the "natural" fit between information technology, markets, and enterprise. Only more recently have these assumptions been seriously challenged by the emergence of new, highly exploitative forms of "platform" working, as embodied by the companies Uber and Deliveroo, and with the rise of "crowdwork" sites such as Amazon's Mechanical Turk. The homeworkers and teleworkers of the 1980s would find the dilemmas of this twenty-first century precariat only too familiar. ${ }^{120}$

\section{IV}

Tracing political struggles over homework opens up a new perspective on market liberalism's triumph in Britain the later twentieth century. In concluding, I offer a brief comparative sketch in order to draw out further the peculiar features of the British case. The history of homework in the United States has been extensively researched by Eileen Boris, who describes a similar ideological cleavage opening up over questions of state intervention in the 1980s. As in Thatcher's Britain, the United States was governed by a New Right administration committed to lowering taxes, cutting public spending, and deregulating markets. Its economy had also seen a surge in homework, both manufacturing and white-collar, as a result of pressure from low-wage competitors overseas, the growth of hi-tech domestic industries, and the creep of office automation. The regulatory context, however, was notably different, with a much longer history of states-level intervention beginning in the 1880s, when the first homework law was passed in New York to prohibit cigar making in tenement blocks. At federal level, homework was heavily regulated by President Roosevelt's National Industrial Recovery Act of 1933, before being ruled unconstitutional by the Supreme Court two years later. More enduring was the Fair Labor Standards Act, under whose provisions a homework ban was introduced in seven industries in the early 1940s, mostly affecting garment manufacture. An uneasy consensus behind these regulations held until 1980, when a highly publicized case brought against knitted garment workers in Vermont reignited the issue. $^{121}$

The battle lines were thus drawn rather differently in the United States, between a Republican administration set on repealing the homework provisions of the Fair Labor Standards Act and a union leadership determined to defend the status quo and see protections extended to other industries. As Boris shows, the debate in the United States was also notable for the manner in which conservative voices

\footnotetext{
${ }^{120}$ One account that makes the link between "old" homeworkers in industry and these new "digital homeworkers" is V. B. Dubal, "The Time Politics of Home-Based Digital Piecework," presentation at The Future of Work in the Age of Automation and AI, University of Toronto, 15 May 2020, Ethics in Context, https://c4ejournal.net/2020/07/04/v-b-dubal-the-time-politics-of-home-based-digital-piecework2020-c4ej-xxx/.

${ }^{121}$ Boris, Home to Work, chap. 11, Eileen Boris, "Regulating Industrial Homework: The Triumph of 'Sacred Motherhood," Journal of American History 71, no. 4 (1985): 745-63.
} 
appropriated liberal-feminist arguments by framing the issue as one concerning a woman's "right" to earn. A republican senator from Utah, Orrin Hatch, introduced a Freedom of Workplace Act in 1984 that asserted the homeworker's right "to be able to support your family in the privacy of your home."122 The Conservative Heritage Foundation also backed abolition, arguing that preserving the laws would be "a serious blow to thousands of women seeking financial independence."123 This language was deployed by the Vermont knitters themselves, who protested that they were not exploited, chose freely to work at home, and had no need for "protection" from the federal government. This alliance between free-market Republicans and a vocal section of the homeworking workforce undoubtedly helps to explain why the Reagan administration was successful in repealing five of the seven bans by 1988. By contrast, in Britain no such alliance existed. As we have seen, some employers insisted that their workers preferred to earn at home, but homework campaigners were united in their demands for greater state protection, and those demands carried a strong socialist-feminist inflection. Hakim's alternative analysis won supporters in government but offered no rallying cry for a grassroots movement of homeworkers opposed to state intervention. To answer the question originally posed-why did governments fail to act on homework?-therefore requires a different explanation. In the British case, we find it in the construction and reception of official data in the 1980s, and in the decoupling of "old" and "new" forms of homework wrought by dominant narratives of the postindustrial economy, especially in the techno-utopian imagination of the modernizing left.

Such a comparative approach might be usefully extended to include other European states, where labor market policies have historically reflected the influence of diverse social and political traditions set against the integrative effects of European Communities/ European Union membership, especially after the creation of the European Single Market in 1992.124 The deregulatory strategy adopted by British governments from the 1980s should be situated within this larger comparative frame, in which each state followed its own pathway toward "flexibilisation." In his official enquiry into modern working practices published in 2017, former New Labour advisor Matthew Taylor referred to the merits of a "British way" in labor market policy, describing Britain's "successful record in creating jobs, including flexible jobs which open up work to people with different needs and priorities and at different stages of life." 25 The British story had its peculiar features, but they need to be adequately explained rather than celebrated. If the Western world experienced a "market turn" in the late twentieth century, it is best understood by specifying its local, particular histories. Similarly, if homeworking becomes a permanent norm for white-collar workers beyond the current pandemic, it will be vital to locate this practice in the longer-term trajectories of market liberalism under conditions of postindustrial modernity.

122 Boris, Home to Work, 350.

${ }^{123}$ Boris, 351.

${ }^{124}$ Colin Crouch, Industrial Relations and European State Traditions (Cambridge, 1993); Gosta EspingAndersen, The Social Foundations of Post-Industrial Economies (Oxford, 1999); Claire Wallace, "Work Flexibility in Eight European Countries: A Cross-National Comparison,” Czech Sociological Review 39, no. 6 (2003): 773-94.

125 Taylor, Good Work, 7. 